University of Nebraska - Lincoln

DigitalCommons@University of Nebraska - Lincoln

Faculty Publications from the Harold W. Manter Laboratory of Parasitology

October 2004

\title{
New species of Cinclotaenia Macy, 1973 (Cyclophyllidea: Dilepididae) from Cinclus leucocephalus Tschudi (Passeriformes: Cinclidae) in Bolivia
}

\author{
Boyko B. Georgiev \\ Bulgarian Academy of Sciences, bbg@ecolab.bas.bg \\ Scott Lyell Gardner \\ University of Nebraska - Lincoln, slg@unl.edu
}

Follow this and additional works at: https://digitalcommons.unl.edu/parasitologyfacpubs

Part of the Parasitology Commons

Georgiev, Boyko B. and Gardner, Scott Lyell, "New species of Cinclotaenia Macy, 1973 (Cyclophyllidea: Dilepididae) from Cinclus leucocephalus Tschudi (Passeriformes: Cinclidae) in Bolivia" (2004). Faculty Publications from the Harold W. Manter Laboratory of Parasitology. 35.

https://digitalcommons.unl.edu/parasitologyfacpubs/35

This Article is brought to you for free and open access by the Parasitology, Harold W. Manter Laboratory of at DigitalCommons@University of Nebraska - Lincoln. It has been accepted for inclusion in Faculty Publications from the Harold W. Manter Laboratory of Parasitology by an authorized administrator of DigitalCommons@University of Nebraska - Lincoln. 


\title{
NEW SPECIES OF CINCLOTAENIA MACY, 1973 (CYCLOPHYLLIDEA: DILEPIDIDAE) FROM CINCLUS LEUCOCEPHALUS TSCHUDI (PASSERIFORMES: CINCLIDAE) IN BOLIVIA
}

\author{
Boyko B. Georgiev and Scott L. Gardner* \\ Central Laboratory of General Ecology, Bulgarian Academy of Sciences, 2 Gagarin Street, Sofia-1113, Bulgaria. e-mail: bbg@ecolab.bas.bg
}

\begin{abstract}
Two new species of Cinclotaenia (Cyclophyllidea: Dilepididae) are described from the small intestine of Cinclus leucocephalus (Aves: Passeriformes: Cinclidae) collected in the Yungas region of Bolivia. Cinclotaenia minuta $\mathrm{n}$. sp. is characterized by possessing a minute strobila with a maximum body length of $1.58 \mathrm{~mm}$, consisting of 5-10 proglottids, 19-22 rostellar hooks with lengths from 16 to $17 \mu \mathrm{m}, 12-17$ testes per proglottid, and eggs forming packets without filaments. Cinclotaenia boliviensis $\mathrm{n}$. sp. has bandlike strobila with a length up to $26 \mathrm{~mm}$ with $67-74$ proglittids, 22 rostellar hooks with length 39-42 $\mu \mathrm{m}, 43-68$ testes, and eggs forming packets possessing long filaments. The systematic position in Cinclotaenia of cestodes lacking filaments on the egg packets is confirmed. This is the first record of species of Cinclotaenia in dippers from Bolivia and also the first report of cestodes from Cinclus sp. in the Neotropical Region.
\end{abstract}

Members of the Cinclidae, commonly called dippers or water ouzels, occupy suitable habitat near and around primary streams and lakes in mountainous areas on all continents except Australia and Antarctica. Cinclus cinclus Linnaeus, 1758 is most widespread, with disjunct populations occurring in Northern Africa, Europe, and Asia. Cinclus pallasii Temminck, 1820 occurs in eastern and southeastern Asia whereas Cinclus mexicanus Swainson, 1827 occurs in America from the sub-Arctic in Alaska, south into northern Panama and possibly northeastern Venezuela. Two species are known from the Neotropical Region, including Cinclus leucocephalus Tschudi, 1844 with a distribution extending from Venezuela southward through the Andes into central Bolivia and Cinclus schulzi Cabanis, 1883 occupying a small range in the Yungas of southern Bolivia and northern Argentina (Brewer, 2001).

Cinclids possess an extremely specific cestode fauna (Oshmarin, 1968; Spasskaya and Spasskii, 1977; Georgiev and Genov, 1985; Macko et al., 2003) with all described species up to the present assignable to the Dilepididae. Macy (1973) first described Cinclotaenia filamentosa Macy, 1973 from C. mexicanus collected on and near streams flowing into the Columbia River in the Cascade Range of northern Oregon. He described this species and created a new monotypic genus mostly on the basis of the structure of the uterus with ripe eggs being held in “packets," each containing 8-12 eggs, and each packet supporting numerous long and thin filaments.

Subsequently, Spasskaya and Spasskii (1977) erected Borgarenkolepis Spasskaya and Spasskii, 1977 for the dilepidids from dippers in the Palearctic. Species that were allocated to this genus included the type species, Borgarenkolepis tarnogradskii (Dinnik, 1927), Borgarenkolepis cincli Spasskaya and Borgarenko in Spasskaya and Spasskii, 1977, Borgarenkolepis dehiscens (Krabbe, 1879), and Borgarenkolepis polyarthra (Krabbe, 1882). Georgiev and Genov (1985) found that the type species of Cinclotaenia and Borgarenkolepis were very similar, including the presence of egg packets in both; and they synonymized the genera, transferring B. tarnogradskii to Cinclotaenia and considering B. cincli, B. dehiscens, and B. polyar-

Received 9 September 2003; revised 12 March 2004; accepted 16 March 2004.

* H. W. Manter Laboratory of Parasitology, University of Nebraska State Museum, University of Nebraska-Lincoln, Lincoln, Nebraska 68588-0514. thra as species incertae sedis. Bona (1994) adopted this generic synonymy and placed $B$. dehiscens in Cinclotaenia on the basis of his observations. Recently, 2 additional species of Cinclotaenia were described (Macko and Špakulová, 2002; Špakulová et al., 2002), including Cinclotaenia georgievi Macko and Špakulová, 2002 from C. cinclus in Slovakia and Bulgaria and Cinclotaenia paradehiscens Špakulová, Macko \& Macková, 2002 from the same host species in Slovakia. Macko and Špakulová (2002) and Macko et al. (2003) also considered B. cincli and $B$. polyarthra as species incertae sedis. Georgiev and Genov (1985) analyzed the published records of dilepidid species originally described from dippers that have been reported from other families of birds and considered most of doubtful validity.

At present, no information exists on the parasites of dippers in the Neotropical Region. The present article contains the descriptions of 2 unknown species of dilepidid cestodes collected from $C$. leucocephalus in Bolivia.

\section{MATERIALS AND METHODS}

\section{Collection locality}

During an extensive survey of the parasites of mammals of Bolivia (Anderson, 1997; Gardner and Pérez-Ponce de León, 2002), 1 of us (S.L.G.) recovered a single individual dipper (C. leucocephalus) that had been caught in a mist net that was being used to capture bats early on the morning of 3 August 1992 at Rio Aceromarca, Departamento de La Paz, Bolivia.

Immediately upon capture, the bird was killed with chloroform, examined for parasites, and prepared as a museum specimen. The air sacs and pleural and peritoneal cavities were opened and examined for parasites, and the intestines were removed, placed in a dish of saline, opened longitudinally, and transferred to cool distilled water for a few minutes. After the cestodes were relaxed, the larger specimens were removed and fixed in hot $10 \%$ buffered formalin solution. Minute cestodes from the duodenum were fixed directly in the vial in hot $10 \%$ buffered formalin. All material was transported and stored until examination in snap-cap vials in $10 \%$ buffered formalin solution. In the laboratory, specimens were removed using a stereo dissecting microscope, washed in water, and transferred to $70 \%$ ethanol. Specimens were stained in iron acetocarmine, dehydrated in an ethanol series, cleared in eugenol, and mounted in Canada balsam. Some scolices or entire specimens were mounted in Berlese medium to facilitate adequate observations of rostellar hooks, cirrus armament, and embryonic hooks. Ripe eggs were studied in both whole mounts of stained cestodes and temporary mounts of dissected gravid proglottids in distilled water. Details on the number of specimens and structures measured are given in the text about each species.

Holotype specimens were deposited in the Parasite Collection of the Harold W. Manter Laboratory of Parasitology, the University of Ne- 
braska-Lincoln (HWML), paratypes were deposited in the HWML, U.S National Parasite Collection, Beltsville, Maryland (USNPC), and The Natural History Museum, London, U.K. (BMNH). Some paratypes were retained in the collection of the senior author.

Measurements of the testes, vas deferens, cirrus sac, vitellarium, ovary, vagina, and seminal receptacle were taken only from fully developed mature proglottids. Mensural data are presented as range, mean in parentheses, and number of measurements or counts taken (n). Measurements are given in micrometers unless otherwise stated. Terms used for developmental stages of proglottids correspond to those previously defined by Georgiev and Vaucher (2001).

\section{DESCRIPTION}

\section{Cinclotaenia minuta n. sp.}

(Figs. 1-8)

Body minute (Fig. 1), when fully developed $0.85-1.58 \mathrm{~mm}$ $(1.26 \mathrm{~mm}, \mathrm{n}=7)$ long. Strobila wedge shaped, consisting of 5-10 $(8, \mathrm{n}=7)$ proglottids, e.g., 3 juvenile, 2 premature, 3 mature, 1 postmature, and 1 gravid proglottid. Maximum width at pregravid and gravid proglottids, 360-560 (430, $\mathrm{n}=12)$. Scolex well outlined from strobila by narrower neck, with maximum diameter at level of suckers, 210-250 (229, $\mathrm{n}=11)$; anterior part of scolex protruded (Fig. 2). Rostellar apparatus musculoglandular. Rostellum elliptical to fungiform, 70-84 (76, $\mathrm{n}=7)$ long, with maximum diameter of $32-41(38, \mathrm{n}=9)$ at hook crown, with thick walls consisting mostly of circular musculature; glandular cells present within rostellum. Rostellar pouch thin walled, elliptical, $118-179(147, \mathrm{n}=8)$ long, reaching level almost at posterior margin of suckers with maximum width about middle, 68-93 (81, $\mathrm{n}=10)$; filled with intensely stained glandular tissue (Fig. 2). Rostellar hooks 20-22 (n = 9) in number, situated in 2 regular rows; 19 hooks only in 1 specimen. Anterior hooks (Fig. 3) 16-17 $(\mathrm{n}=6)$ long, posterior hooks (Fig. 4) 16-17 $(\mathrm{n}=4)$ long; no difference in shape of anterior and posterior hooks observed. Suckers round, with apertures directed anterodorsally and anteroventrally, with diameter $98-118(112, \mathrm{n}=24)$; their musculature moderately developed. Neck distinct, 73-131 $(98, \mathrm{n}=12)$ wide at narrowest part; first proglottids appearing at 68-143 (92, n = 10) from posterior margins of suckers. Ventral osmoregulatory canals 3 $6(n=10)$ in diameter, forming transverse anastomosis along posterior margin of each proglottid. Dorsal osmoregulatory canals 1-3 $(\mathrm{n}=10)$ in diameter. Proglottids craspedote, usually wider than long at all developmental stages except gravid, which might be almost as long as wide; occasionally, mature proglottids slightly longer than wide. Genital pores irregularly alternating, situated in anterior third of lateral margin of mature and far anterior in gravid proglottids. No genital papilla. Genital atrium (Fig. 6) simple, infundibular, surrounded by intensely stained cells. Genital ducts usually passing dorsally to osmoregulatory canals, occasionally in same strobila, also passing between osmoregulatory canals.

Testes $12-17(14, \mathrm{n}=20)$ in number, forming compact group posterior to vitellarium and ovary situated in posterior half to two thirds of median field. In some proglottids, testes may overlap vitellarium and posterior margins of ovary (Fig. 5). Maximum diameter of fully developed testes 46-63 (55, $\mathrm{n}=12)$. Vas deferens diameter $4-7(6, \mathrm{n}=12)$, forming coils in median field near anterior margin of proglottid; glandular prostate cells not observed. Cirrus sac usually situated slightly oblique in proglottid, elliptical, thick walled, $72-93$ by $23-34$ ( 83 by $29, \mathrm{n}=$
12), overlapping or crossing about its middle poral osmoregulatory canals; in some proglottids, when cirrus fully evaginated (Fig. 7), cirrus sac oval, measuring $59-72$ by $27-39$ ( 65 by 34 , $\mathrm{n}=5$ ). Internal vas deferens forming several coils in aporal half of cirrus sac (Figs. 5, 6). Evaginated cirrus cylindrical, unarmed, with diameter 11-13 $(\mathrm{n}=11)$.

Vitellarium median, reniform to oval, lobed, $48-88(66, \mathrm{n}=$ 12) wide. Ovary bilobed, consisting of deep, almost transverse lobes; 2 lobes connected by wide isthmus; occupying entire width of median field, 147-273 (202, $\mathrm{n}=12)$ wide. Mehlis' gland globular, 20-38 (23, $\mathrm{n}=12)$ in diameter, not distinct in some proglottids. Seminal receptacle oval, extending from level of aporal end of cirrus sac to Mehlis' gland, 61-122 by 36-59 ( 78 by $43, \mathrm{n}=12$ ) when filled (Figs. 5,6 ). Vagina opens posteriorly to male pore and passing posteriad to cirrus sac; copulatory part thick walled, lumen with diameter 4-9 $(6, \mathrm{n}=12)$, surrounded by cellular sleeve with diameter $11-16(13, \mathrm{n}=$ 12).

Uterine development rapid. Uterus first appearing as a transversely elongate sac occupying whole median field, its lateral branches may slightly pass into lateral fields; ventral to degenerating ovary and vitellarium; uterine wall forming deep diverticula. Fully developed uterus thick walled; walls of diverticula creating impression for compartmentalization of organ (Fig. 7). Eggs forming egg packets, each containing 10-18 eggs (Figs. $7,8)$. Outer envelope thin, with irregular shape, often not distinct in whole mounts; diameter of eggs in whole mounts 29$38(33, \mathrm{n}=20)$, in distilled water 46-60 (53, $\mathrm{n}=20)$. Embryophores thick walled, spherical, with diameter 23-29 (28, n $=20)$. Oncospheres oval, with diameter 16-19 (18, $\mathrm{n}=20)$. Embryonic hooks of central pair 8-10 $(n=10)$ long, of lateral pairs $6-8(\mathrm{n}=10)$.

\section{Taxonomic summary}

Type host: Cinclus leucocephalus Tschudi, 1844 (Aves: Passeriformes: Cinclidae) (1 individual).

Site of infection: Anterior one third of small intestine (duodenum).

Symbiotype (see Frey et al., 1992). Holosymbiotype: Cinclus leucocephalus Tschudi, 1844. Female. Museo Nacional de Historia Natural, La Paz, Bolivia, Colección Boliviana de Fauna, Catalog no. 2439. Collected on 3 August 1992. Field collection no. SED751 (by Susan E. Davis), necropsy by S.L.G. (SLG230-92).

Type locality: Rio Aceromarca, Departamento de La Paz, Bolivia, $16^{\circ} 19^{\prime} \mathrm{S}, 67^{\circ} 53^{\prime} \mathrm{W}$, elevation $2,990 \mathrm{~m}$.

Specimens studied: Twenty-one specimens from duodenum (mostly fragmented during isolation), including 7 entire specimens, 10 stained scolices, 4 scolices in Berlese medium, and 13 stained strobilar fragments.

Specimens deposited: Holotype HWML 45725; Paratypes HWML 45726-45736; MHNG (INVE) 35061-35063.

Etymology: The species name refers to the size of the organism, which is extremely small.

\section{Diagnosis}

Cinclotaenia minuta n. sp. resembles a group of species within the genus that are characterized by rather short rostellar hooks (less than $20 \mu \mathrm{m}$ ), including $C$. filamentosa from the Nearctic 

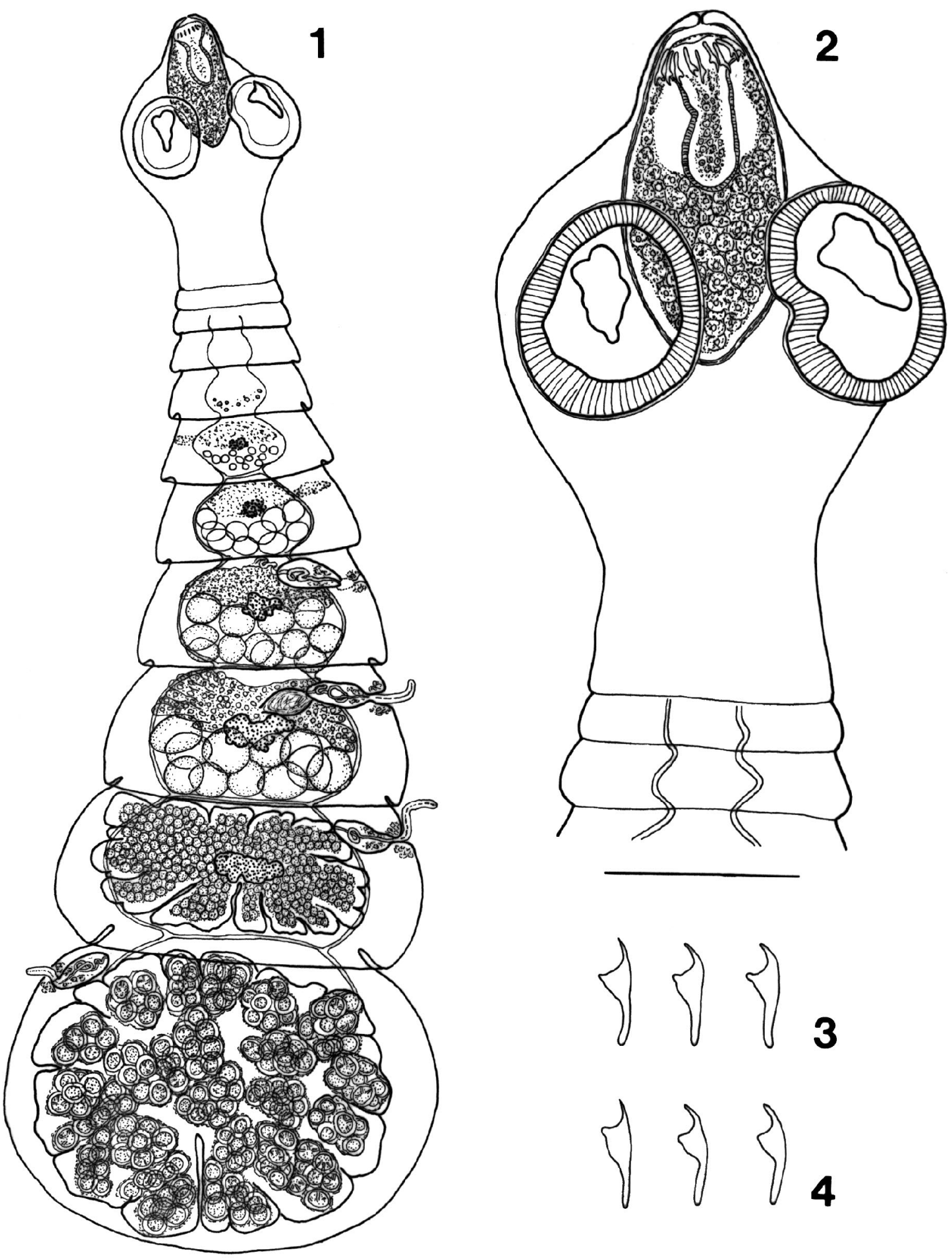

Figures 1-4. Cinclotaenia minuta n. sp. 1. General view. 2. Scolex. 3. Anterior rostellar hooks. 4. Posterior rostellar hooks. Bar $=250 \mu \mathrm{m}$ (Fig. 1), $100 \mu \mathrm{m}$ (Fig. 2), and $20 \mu \mathrm{m}$ (Figs. 3, 4). 

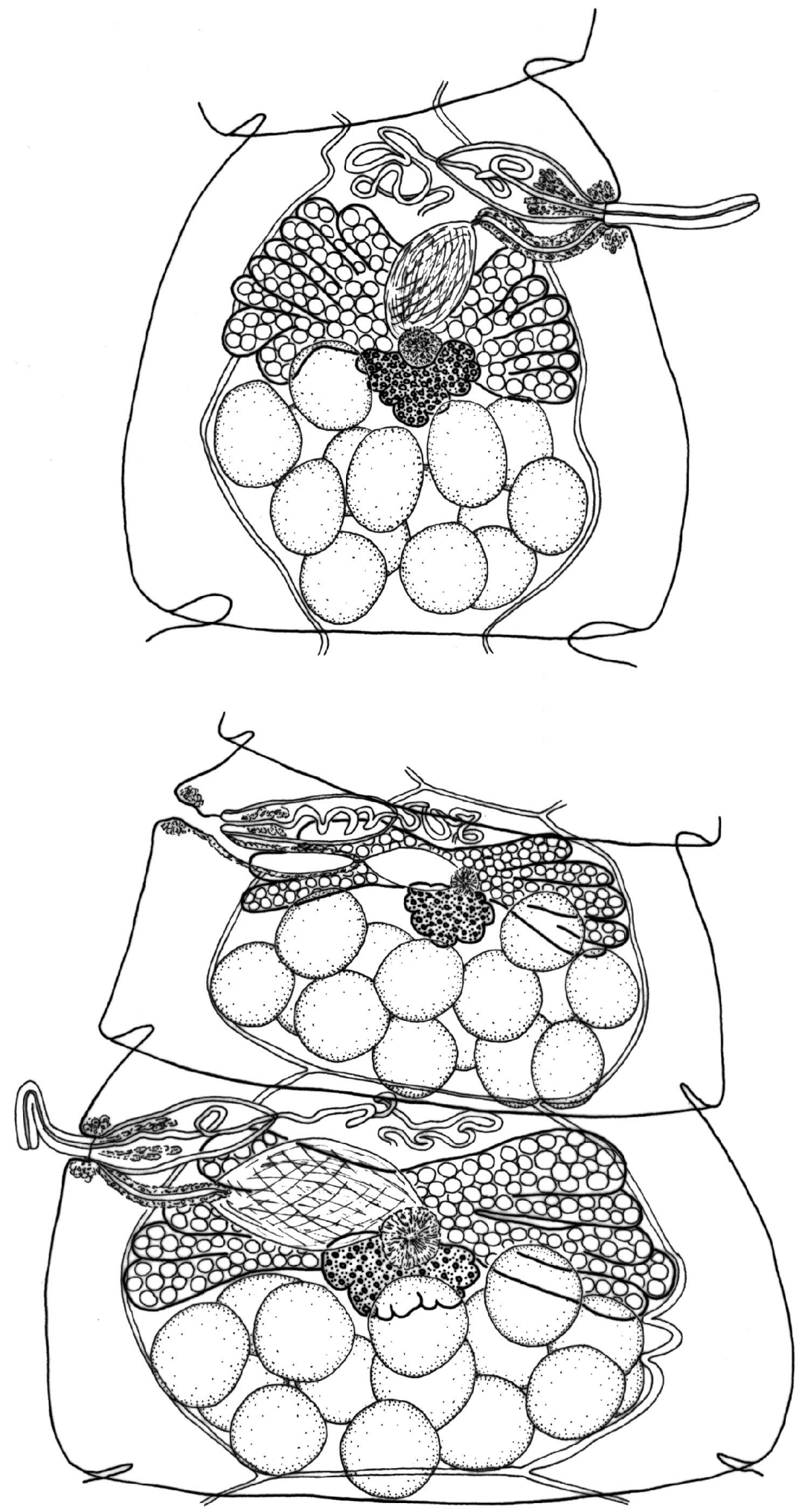

Figure 5. Cinclotaenia minuta n. sp. Mature proglittids. Bar $=100 \mu \mathrm{m}$. 

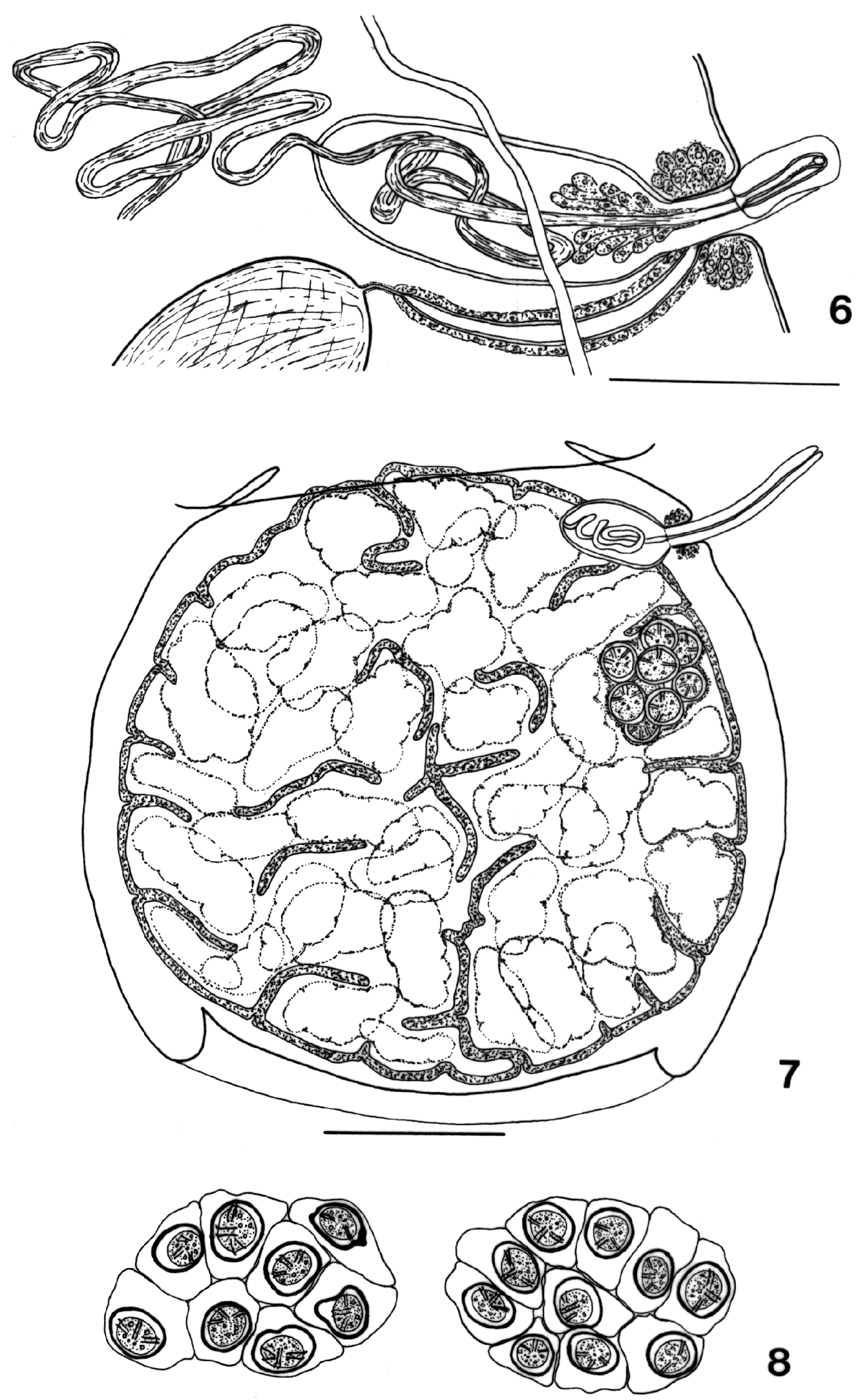

8

Figures 6-8. Cinclotaenia minuta n. sp. 6. Genital ducts in mature proglottid. 7. Gravid proglottid. 8. Egg packets examined in distilled water Bar $=50 \mu \mathrm{m}$ (Fig. 6) and $100 \mu \mathrm{m}$ (Figs. 7, 8). 


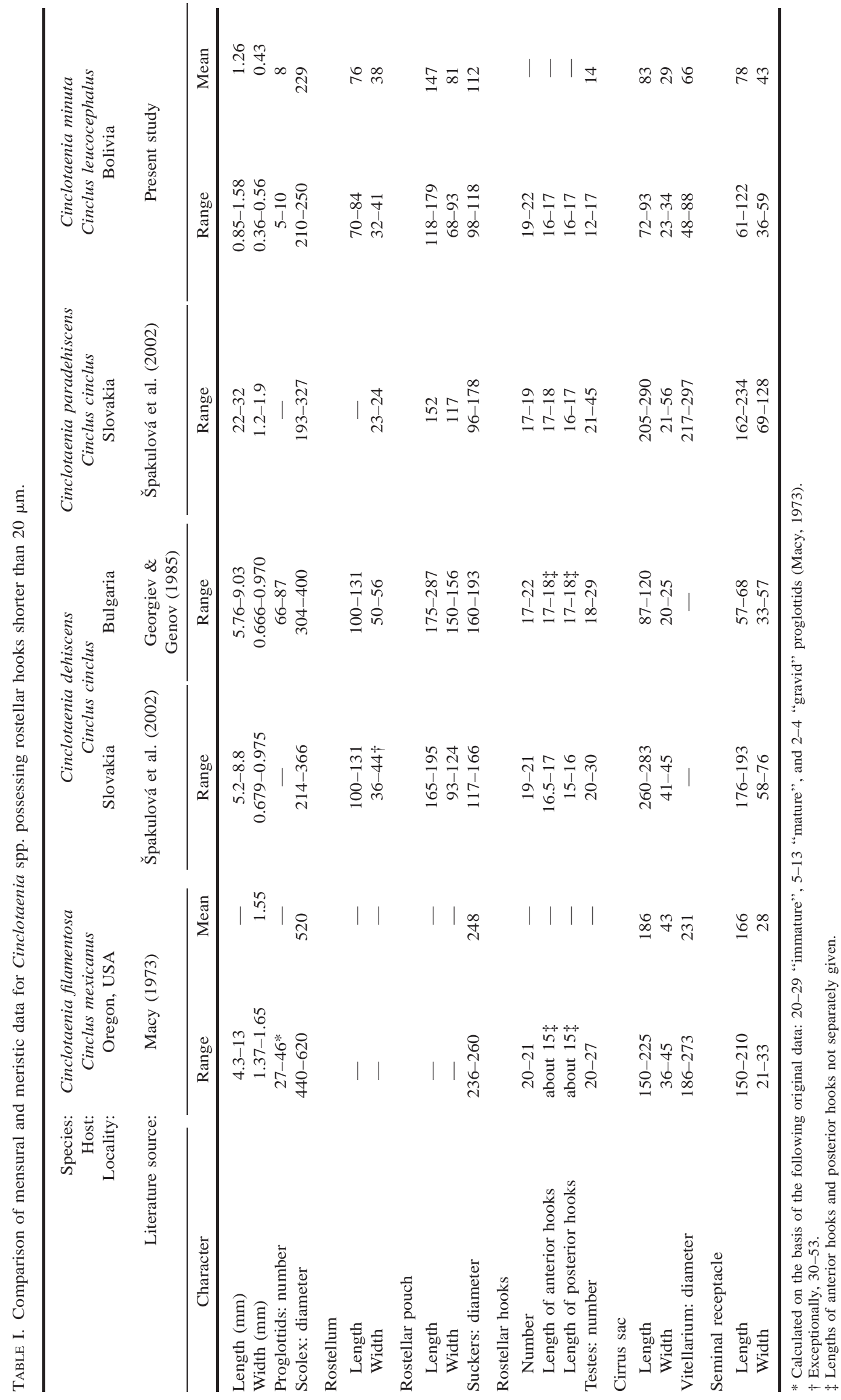


and Cinclotaenia dehiscens and C. paradehiscens from dippers in the Palearctic Region (Table I); however, C. minuta can be recognized as distinct from the 3 species mentioned above by possessing a very small body, not exceeding $2 \mathrm{~mm}$ in length. The shortest length reported for a gravid specimen of $C$. filamentosa was $4.3 \mathrm{~mm}$ reaching a maximum length of $13 \mathrm{~mm}$ (Macy, 1973). The strobila of C. minuta consists of a very small number of proglottids (5-10) and exhibits a very rapid maturation (Fig. 1). In contrast, the other 3 species are characterized by bandlike strobila containing numerous proglottids (Table I). In addition, $C$. minuta differs from the other 3 species by having fewer testes and a smaller cirrus sac (Table I).

\section{Cinclotaenia boliviensis n. sp.}

(Figs. 9-16)

Body elongate, when fully developed $20-26 \mathrm{~mm}(22.5 \mathrm{~mm}$, $\mathrm{n}=3$ ) long, consisting of 67-74 (71, $\mathrm{n}=3)$ proglottids. Maximum width of whole specimens at pregravid proglottids, 1.20 $1.44 \mathrm{~mm}(1.32 \mathrm{~mm}, \mathrm{n}=3)$. Gravid fragments $1.40-1.64 \mathrm{~mm}$ $(\mathrm{n}=2)$ wide. Scolex well outlined from strobila by narrower neck, with maximum diameter at level of suckers, 371-411 (n $=2$ ); anterior part of scolex protruded. Rostellar apparatus musculoglandular. Rostellum mushroom shaped, 215-228 $(n=2)$ long, with maximum diameter of 103-108 $(\mathrm{n}=2)$ at hook crown; rostellar walls thick, consisting mostly of circular musculature; numerous glandular cells within rostellum. Rostellar pouch thin walled, elliptical, 255-295 $(\mathrm{n}=2)$ long, extending posteriad to level at beginning of neck; maximum width about middle of pouch, 148-157 ( $=2)$; filled with intensely stained, strongly developed glandular tissue (Fig. 9). Rostellar hooks 22 $(\mathrm{n}=3)$ in number, situated in 2 regular rows. Anterior hooks 39-42 (41, $\mathrm{n}=10)$ long, length of blade 11-12 ( $\mathrm{n}=10)$. Posterior hooks 39-42 (41, $\mathrm{n}=8)$ long, length of blade 11-12 $(\mathrm{n}=10)$. No difference in shape of anterior and posterior hooks. Suckers round, $143-170(155, \mathrm{n}=8)$ in diameter, apertures directed anterodorsally and anteroventrally; musculature of suckers moderately developed. Neck distinct, 201-224 (n = 2) wide at narrowest part; first proglottids appearing at 160$220(n=2)$ from posterior margins of suckers. Ventral osmoregulatory canals with diameter of $29-38(34, \mathrm{n}=10)$ in mature proglottids, forming transverse anastomosis along posterior margin of each proglottid. Dorsal osmoregulatory canals 6-13 $(8, \mathrm{n}=10)$ in diameter. Proglottids craspedote, usually wider than long at all developmental stages (Figs. 12, 14, 15). Genital pores irregularly alternating, mostly in short series, e.g., . . 1, $5,1,4,1,1,7,1$, or $\ldots 2,1,2,2,4,2,4,2,1,1,1,2,2,3$, situated in anterior half of lateral margin of mature and far anterior in gravid proglottids, respectively (Figs. 12, 15). Genital atrium 16-27 (23, n = 10) deep, with infundibular orifice and cylindrical proximal part $14-23(17, \mathrm{n}=10)$ in diameter; situated on tall, well-expressed genital papilla with walls containing strongly developed musculature and glandular cells. Genital ducts passing between osmoregulatory canals $(n=17)$.

Testes $43-68(57, \mathrm{n}=10)$ in number, arranged in 2 or 3 layers, forming compact group in posterior half of median field, posteriorly to vitellarium and ovary; occasionally overlapping vitellarium and posterior margins of ovary (Fig. 12); maximum diameter of fully developed testes $81-98(87, \mathrm{n}=10)$. External vas deferens with diameter $11-15$, forming coils in poral half of median field near anterior proglottid margin; prostate cells not seen. Cirrus sac oblique, elongate-elliptical, thin walled, $174-228$ by $36-49$ (201 by $45, \mathrm{n}=17$ ), situated mostly in poral part of lateral field, often overlapping poral osmoregulatory canals; aporal part sometimes slightly situated in median field; intensely stained cells in poral part of cirrus sac. Internal vas deferens slightly coiled (Figs. 12, 13). Cirrus cylindrical, 61-63 ( $=3)$ long, $14-16(15, \mathrm{n}=7)$ in diameter with slightly tapering tip, unarmed.

Vitellarium disposed porally, reniform to U shaped, deeply lobed, 142-163 (149, n = 10) wide. Ovary bilobed, consisting of long, almost transverse, digitiform lobes, often connected by distinct anastomoses, i.e., organ assuming reticulate appearance; 2 wings connected by wide isthmus; occupying entire width of median field, distal parts of lateral lobes overlapping osmoregulatory canals. Mehlis' gland globular, with diameter 20-24 (22, $\mathrm{n}=10)$. Seminal receptacle thin walled, oval, dorsal to ovary, extending from level of cirrus sac antiporal end to poral half of vitellarium; when filled 143-241 by 98-156 (196 by $137, \mathrm{n}=14$ ) (Figs. 12, 13). Vagina opening posteriorly to opening of cirrus sac and passing posteriorly to it; copulatory part with thick-walled lumen with diameter $6-8(7, \mathrm{n}=10)$, surrounded by cellular sleeve; diameter of copulatory part 22 $29(25, \mathrm{n}=10)$. Conductive part thin and short, often coiled.

Uterus first appearing ventrally to vitellarium, ovary, and testes as a reticular structure occupying whole median field; its lateral branches passing into lateral fields. With degeneration of male and female gonads and further uterine development, uterus becoming divided into many compartments (Fig. 14); uterine wall forming deep diverticula; at this stage, eggs not forming packets. Fully developed uterus thick walled, with strongly developed uterine epithelium (Fig. 15). Fully developed eggs forming egg packets (Fig. 16), each containing 12-32 eggs. Outer envelope thin, provided with long filaments 370-390 in length (not distinct in whole mounts). Embryophore consisting of granular external layer and refractive oval layer with diameter 24-29 $(27, \mathrm{n}=10)$. Oncosphere spherical to slightly oval, $16-21(19, \mathrm{n}=10)$ in diameter. Embryonic hooks of central pair 13-14 long, of lateral pairs 9-10 long.

\section{Taxonomic summary}

Type host: Cinclus leucocephalus Tschudi, 1844 (1 individual).

Site of infection: Anterior one third of small intestine (duodenum).

Type locality: Rio Aceromarca, Departamento de La Paz, Bolivia, $16^{\circ} 19^{\prime} \mathrm{S}, 67^{\circ} 53^{\prime} \mathrm{W}$, elevation $2,990 \mathrm{~m}$.

Symbiotype (see Frey et al., 1992). Holosymbiotype: Cinclus leucocephalus Tschudi, 1844. Female. Museo Nacional de Historia Natural, La Paz, Bolivia, Colección Boliviana de Fauna Catalog no. CBF2439. Collected on 3 August 1992. Field collection no. SED751 (by Susan E. Davis), necropsy by S.L.G. (SLG-230-92).

Specimens studied: Three specimens from duodenum, stained and mounted on glass slides as whole mounts (last proglottids pregravid); 1 scolex mounted on a slide in Berlese medium; 2 detached fragments consisting of gravid proglottids.

Specimens deposited: Holotype HWML 45719; Paratypes HWML 45720-45724. 

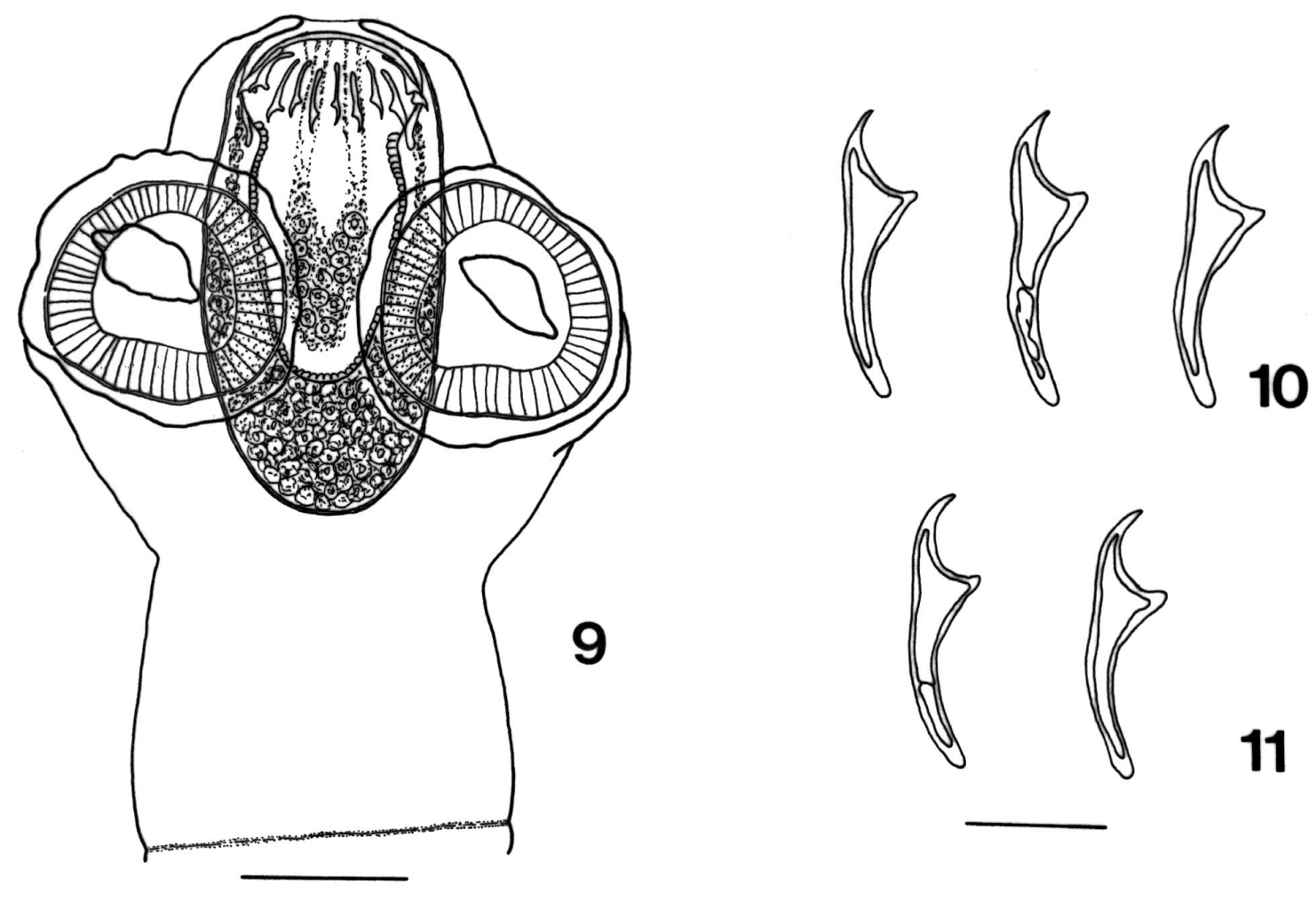

11

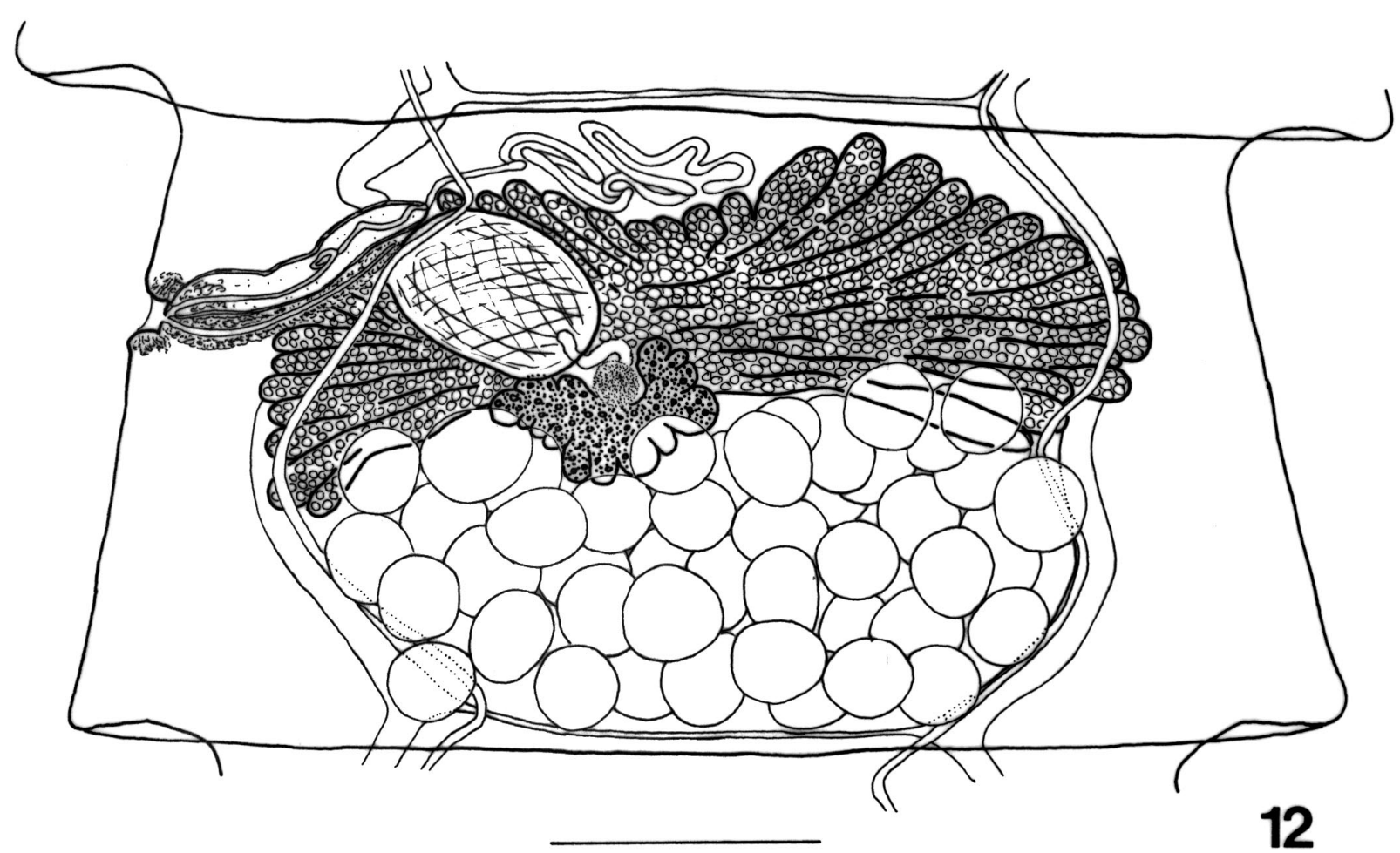

Figures 9-12. Cinclotaenia boliviensis n. sp. 9. Scolex. 10. Anterior rostellar hooks. 11. Posterior rostellar hooks. 12. Mature proglottid. Bar $=100 \mu \mathrm{m}$ (Fig. 9), $20 \mu \mathrm{m}$ (Figs. 10, 11), and $250 \mu \mathrm{m}$ (Fig. 12). 

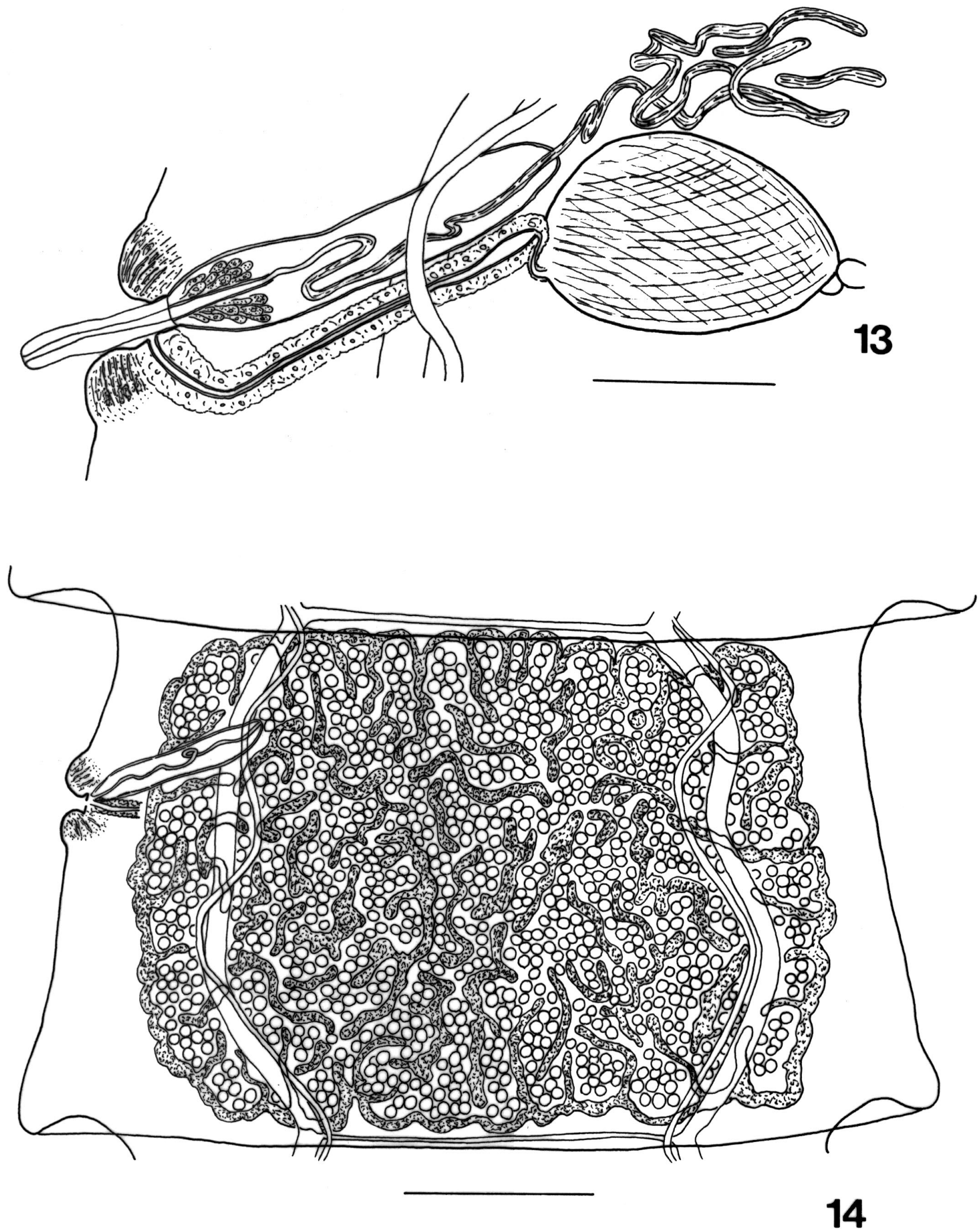

FIGURES 13-14. Cinclotaenia boliviensis n. sp. 13. Genital ducts in mature proglottid. 14. Pregravid proglottid. Bar $=100 \mu \mathrm{m}($ Fig. 13$)$ and $250 \mu \mathrm{m}$ (Fig. 14). 

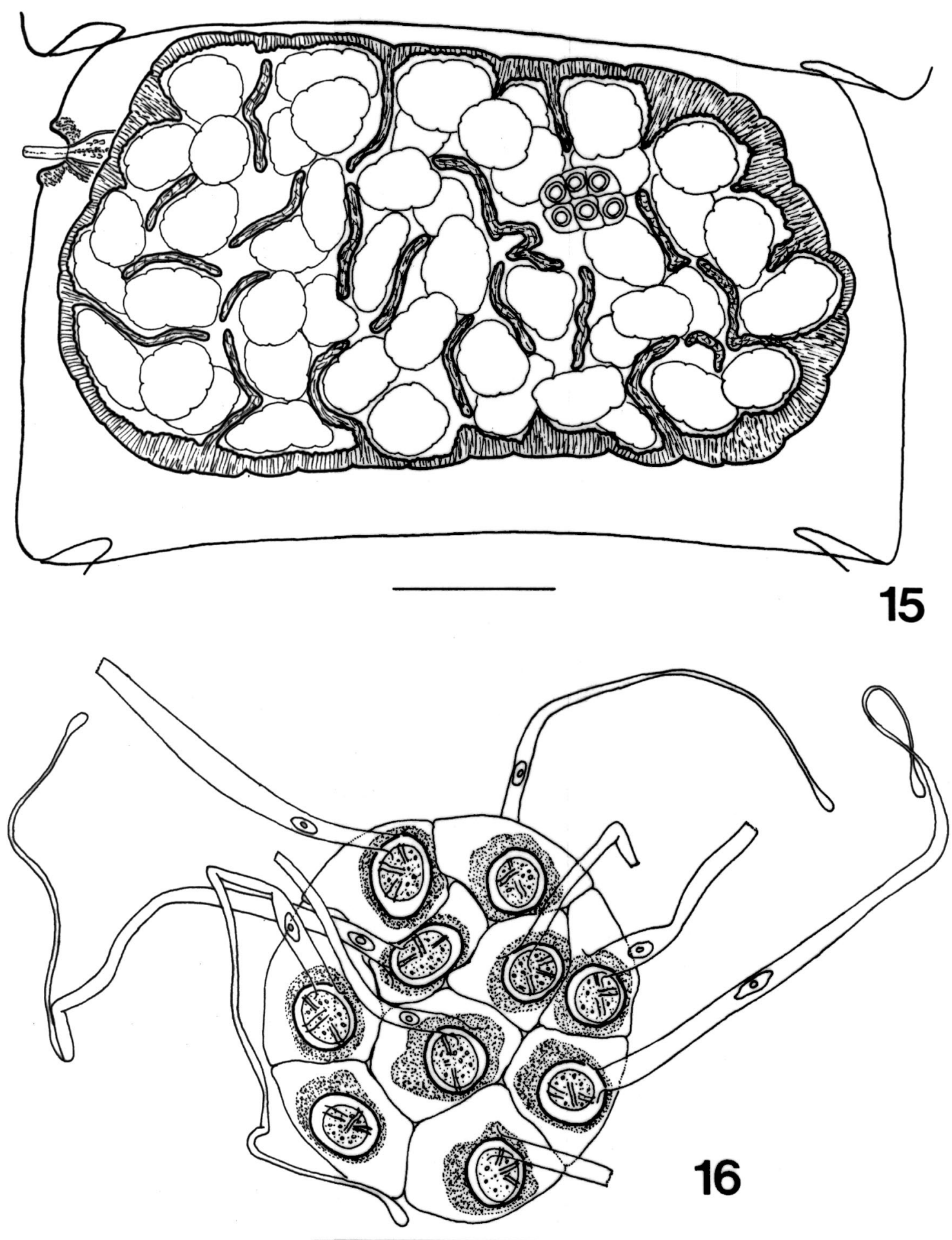

FiguRES 15-16. Cinclotaenia boliviensis n. sp. 15. Gravid proglottid. 16. Egg packets examined in distilled water. Bar $=250 \mu \mathrm{m}($ Fig. 15$)$ and $100 \mu \mathrm{m}$ (Fig. 16).

Etymology: The species name refers to Bolivia, the country in which it was first found.

\section{Diagnosis}

The new species can be diagnosed by the length of the strobila, the length and the shape of rostellar hooks, and the dis- position of the internal organs in mature proglottids, C. boliviensis n. sp. appears closely related to the Palearctic species Cinclotaenia tarnogradskii and C. georgievi. Cinclotaenia boliviensis can be distinguished from both these species in that the rostellar hooks of the new species are longer (Table II) and C. boliviensis has well-expressed muscular genital papilla (Fig. 
13), which has not been described for the other 2 species (Spasskaya and Spasskii, 1977; Georgiev and Genov, 1985; Macko and Špakulová, 2002). In addition, $C$. boliviensis can be recognized as distinct in having a longer rostellum, a larger rostellar pouch, and a much greater number of testes (Table II).

Cinclotaenia boliviensis can be recognized as distinct from the 2 species of dilepidids from dippers that have an uncertain generic allocation, i.e., B. cincli and Taenia (s.l.) polyarthra, by having a greater number and size of rostellar hooks and a greater number of testes (Table II) (Georgiev and Genov, 1985; Macko and Špakulová, 2002; Macko et al., 2003).

\section{DISCUSSION}

After the establishment of Cinclotaenia (for C. filamentosa) by Macy (1973), its definition has been emended several times (Georgiev and Genov, 1985; Bona, 1994; Špakulová et al., 2002; Macko et al., 2003). The presence of filaments on the egg packets in fresh-living specimens, as described by Macy (1973) for C. filamentosa and confirmed by Georgiev and Genov (1985) for C. tarnogradskii, has always been an essential element of the generic diagnosis. Recently, Špakulová et al. (2002) described the formation of egg packets in C. dehiscens and $C$. paradehiscens but did not observe filaments. Because specimens that they studied were derived from preserved material only, they noted, with some uncertainty, the absence of filaments on the egg packets. Our observations on gravid proglottids of $C$. minuta, dissected in distilled water, showed the absence of filaments on the egg packets (Fig. 8). The same method as applied to $C$. boliviensis revealed the presence of filaments (Fig. 16). Therefore, we confirm the amendment of the generic diagnosis proposed by Špakulová et al. (2002). The peculiarity of the structure of the uterus was emphasized in previous studies (Georgiev and Genov, 1985; Bona, 1994; Špakulová et al., 2002; Macko et al., 2003). At present, we cannot add to the interpretations made by these authors.

Until now, species of Cinclotaenia were only known from Cinclus spp. from the Holarctic Region (Macy, 1973; Spasskaya and Spasskii, 1977; Georgiev and Genov, 1985; Macko and Špakulová, 2002; Špakulová et al., 2002). This study provides the first record of species of Cinclotaenia from the Neotropical Region. Because species of Cinclus appear to be monophyletic (Sibley and Monroe, 1990; Brewer, 2001), this host-parasite system appears to be very suitable for a detailed study of tapeworm-avian coevolution and biogeography.

\section{ACKNOWLEDGMENTS}

We thank the mammal collection crew of 1992 including S. Anderson, S. V. Brant, J. Salazar-Bravo, S. Davis, M. Blair, and J. Dunnum. We also thank the staff and students of the Colección Boliviana de
Fauna of the Museo Nacional de Historia Natural, La Paz, for assistance with all phases of collecting and logistics. This work was supported by United States National Science Foundation Grants BSR8612329, BSR9024816, DEB9496263, DEB9631295 to S.L.G., BSR8408923 to T. L. Yates, and BSR8316740 to S. Anderson. We are grateful to P. Nikolov for reading the manuscript. Thanks also to Agustín JiménezRuiz for lab assistance.

\section{LITERATURE CITED}

ANDERSON, S. 1997. Mammals of Bolivia, taxonomy and distribution Bulletin of the American Museum of Natural History 231: 1-652.

Bona, F. V. 1994. Family Dilepididae Railliet \& Henry, 1909. In Keys to the cestode parasites of vertebrates, L. F. Khalil, A. Jones, and R. A. Bray (eds.). CAB International, Wallingford, U.K., p. 443554.

Brewer, D. 2001. Wrens, dippers and thrashers. Yale University Press, New Haven, Connecticut, p. 199-207.

Frey, J. K., D. W. Duszynski, W. L. Gannon, T. L. Yates, and S. L. GARDNER. 1992. Designation and curation of type host specimens (Symbiotypes) for new parasite species. Journal of Parasitology 78: 930-932.

GARDNer, S. L., AND G. PÉReZ-PonCe de LeÓn. 2002. Yungasicola travassosi gen. n., sp. n. (Digenea: Dicrocoeliidae: Eurytrematinae) from two species of grass mice of the genus Akodon Meyen (Rodentia: Muridae) from the Yungas of Bolivia. Comparative Parasitology 69: 51-57.

Georgiev, B. B., AND T. Genov. 1985. Taxonomy and morphology of cestodes, parasites of Cinclus cinclus L. in Bulgaria. Parasitologia Hungarica 18: 49-62.

-, AND C. VAucher. 2001. Revision of the genus Parvirostrum Fuhrmann, 1908 (Cestoda, Cyclophyllidea, Paruterinidae). Systematic Parasitology 50: 13-29.

KrabBE, H. 1882. Nye Bidtrag til Kundskab om Fuglenes Bændelorme. Det Videnskabelige Selskabs Skrifter, 6. Række, naturvidenskabelig og mathematisk 7: 349-266.

MACKO, J. K., AND M. ŠPAKULOVÁ. 2002. A description of Cinclotaenia georgievi n. sp. (Cestoda: Dilepididae), a tapeworm from the dipper Cinclus cinclus (L.) (Passeriformes: Cinclidae). Systematic Parasitology 52: 75-80.

- _ AND A. Macková. 2003. Tapeworms of the dipper Cinclus cinclus aquaticus Bechstein (Passeriformes: Cinclidae) in the Slovak Republic and a key to cestode species specific to dippers. Helminthologia 40: 59-62.

MACY, R. W. 1973. Cinclotaenia filamentosa gen. et sp. n. (Cestoda: Dilepididae) from the dipper in Oregon. Proceedings of the Helminthological Society of Washington 40: 201-204.

Oshmarin, P. G. 1968. Helminth fauna of dippers in view of the question about the formation of the helminth fauna of animals. Parazity Zhivotnykh i Rasteniy 4: 122-128. [In Russian.]

Sibley, C. G., AND B. L. Monroe JR. 1990. Distribution and taxonomy of birds of the world. Yale University Press, New Haven, Connecticut, $1,111 \mathrm{p}$.

ŠPakulová, M., J. K. Macko, AND A. Macková. 2002. The description of Cinclotaenia paradehiscens $\mathrm{n}$. sp. and its comparison with Cinclotaenia dehiscens (Krabbe, 1879) (Cestoda: Dilepididae), tapeworms of the dipper Cinclus cinclus (L.) (Passeriformes: Cinclidae). Helminthologia 39: 227-231.

Spasskaya, L. P., AND A. A. Spasskit. 1977. Cestodes of birds in the USSR. Dilepididae of terrestrial birds. Izdatel'stvo Nauka, Moscow, Russia, 300 p. [in Russian.] 